\title{
Déja vu and Wind Turbines: A Review of Lived Experiences after Appeals of Ontario Industrial-Scale Wind Power Facilities
}

\author{
Jane Wilson ${ }^{1}$, Carmen Krogh ${ }^{2}$, Paula C. Peel ${ }^{3}$ \\ ${ }^{1}$ Wind Concerns Ontario, Ottawa, Canada \\ ${ }^{2}$ Magentica Research Group, Killaloe, Canada \\ ${ }^{3}$ South Shore Joint Initiative, Prince Edward County Field Naturalists, Wind Concerns Ontario, Milford, Canada \\ Email: *EJaneWilsonRN@gmail.com
}

How to cite this paper: Wilson, J., Krogh, C. and Peel, P.C. (2020) Déja vu and Wind Turbines: A Review of Lived Experiences after Appeals of Ontario Industrial-Scale Wind Power Facilities. Open Access Library Journal, 7: e6276.

https://doi.org/10.4236/oalib.1106276

Received: March 28, 2020

Accepted: May 12, 2020

Published: May 15, 2020

Copyright $\odot 2020$ by author(s) and Open Access Library Inc.

This work is licensed under the Creative Commons Attribution International License (CC BY 4.0).

http://creativecommons.org/licenses/by/4.0/

\begin{abstract}
This paper is a review of reports of lived experiences of residents in ru$\mathrm{ral} / \mathrm{small}-$ town Ontario, Canada and a comparison to the concerns raised during citizen-sponsored appeals of industrial-scale wind power project approvals. We found that the concerns leading to the decisions to appeal power projects have been borne out in real-life experience, as government documents record thousands of complaints about adverse effects on the environment and human health. These findings support the need for enforcement of regulations on wind power operations, and the need to acknowledge that community concerns about large power projects are genuine.
\end{abstract}

\section{Subject Areas}

Health, Justice, Energy

\section{Keywords}

Wind Power, Legal, Justice, Environment, Noise, Government Policy, Public Health

\section{Introduction}

In 2009, the provincial government in Ontario, Canada, enacted legislation called the Green Energy and Green Economy Act (GEA) with the goal of encouraging the development of sources of renewable power in that jurisdiction.

Industrial-scale or grid-scale wind power development was new to Ontario at that time; some municipalities in the province were cautious about the govern- 
ment's plan, and asked for cost-benefit analyses and/or impact analysis before the act was passed [1]. The premier at the time, however, did not want municipalities to be able to veto or hinder wind power proposals; his government designed the Green Energy Act to remove all local land-use planning powers for renewable power generation projects [2].

The forced industrialization of quiet rural communities was the subject of criticism by energy analysts and legal authorities. Professor of Law and Economics Michael Trebilcock wrote soon after the GEA was passed that the government was acting on ideology, not fact or analysis:

The unexamined proposition has been that if it [wind power technology]

is declared green, it deserves no further scrutiny or analysis. The large land footprint of renewable sources of generation often collides with other purposes for use of land. This will set in motion a dynamic of social friction with unintended, unpredictable consequences [3].

One of the consequences of the government's new policy was that Ontario communities, now deprived of input into siting decisions for the wind power projects, took action the only way they could-by using the legislated ability to appeal the government's approval of the projects.

The community concerns about the Ontario wind power projects were reviewed for this paper by noting the grounds for appeals of power projects filed with the government, and then reviewing the basis for formal complaints filed with the government after wind power projects began operating.

The intent of this research was to determine whether there is a link between the concerns which led citizens to appeal the power project approvals, and the nature of post-operational complaints. As far as the authors are aware, no such analysis has been previously published; while some authors considered the appeals and why they failed, that work did not encompass the post-operational experiences for people living inside wind power facilities.

\section{Methodology}

We reviewed the list of appeals filed under the authority of the Ontario Environmental Protection Act (EPA), selected several of the power projects and compared reports of environmental pollution including pollution Incident Reports, i.e., the documents recording the complaints filed with the government, and other indicators of the impact of these projects on host communities. The records of complaints filed with government were obtained via requests under the Freedom of Information and Privacy Act (FOI) made by community group coalition Wind Concerns Ontario. The documents were then examined for the presence of descriptive comments or notations made by government staff and for transcripts or notes of direct quotes from citizens filing the complaints. The content of these notations or comments were then compared to the grounds for the appeals of approvals relative to the individual power projects concerned. 
News media reports were also reviewed in order to ascertain "on the ground" lived experiences by residents, expressed in their own words through interviews.

Government records of complaints of environmental noise were the main focus because that was the reason for the majority of the contacts with government; however, other effects have been noted including shadow flicker or strobe effects from the turbines, and altered water well function which may be connected to wind turbine vibration during construction and operation.

\section{The Ontario Appeal Process}

At the time the Green Energy Act was passed, the government promised that for health and safety, regulations to govern noise levels and setbacks between the industrial-scale wind turbines and Ontario residents' homes would be based on science. In answering concerns about the wind power installations, the premier at the time said “... it's okay to object on the basis of safety issues and environmental standards; if you have real concerns there, put those forward and we must find a way to address those." [4].

According to the provisions of the Environmental Protection Act, if citizens were concerned about the potential for negative effects from a wind power generating facility, they had the option to appeal the government's approval before the Environmental Review Tribunal (ERT). Citizens had just 15 days to file an appeal after a Renewable Energy Approval (REA) had been posted publicly by the government.

The basis on which an appeal could be filed was strictly limited. The ERT posts these guidelines:

Under the Environmental Protection Act, there are only two grounds which can be considered on an appeal by a member of the public. They are that proceeding with the project, as approved by the Director will either:

- cause serious harm to human health, or

- cause serious and irreversible harm to plant life, animal life or the natural environment.

A person challenging the Director's approval of a project must be able to convince the Environmental Review Tribunal, by evidence and argument, that it is more likely than not that one of these two tests has been met. If they do not do so, then the law requires that the Director's decision must be confirmed [5].

The "Director" is a public servant appointed by the Minister as deemed necessary under the Environmental Protection Act, in this case, to oversee Renewable Energy Approvals and their conditions [6].

The goal of the community group or individual in appealing the government approval of a wind power project was presumably to have the approval reversed, or the approval modified to reduce the risks and concerns which were the basis of the appeal. The "Director" issuing the Renewable Energy Approval has the power to take such action according to Part V.0.1, 47.5 Section 3 of the EPA "Other powers", which apply specifically to "Renewable Energy": 
On application or on his or her own initiative, the Director may, if in his or her opinion it is in the public interest to do so,

1) alter the terms and conditions of a renewable energy approval after it is issued;

2) impose new terms and conditions on a renewable energy approval; or

3) suspend or revoke a renewable energy approval, 2009, c. 12, Sched, G.,

s. 4 (1) [7].

Choosing to appeal a wind power approval was, as one law firm put it, an "uphill battle":

Parties appealing [Renewable Energy Approvals] face an uphill battle. The grounds are difficult to satisfy and the burden of proof lies upon the party alleging the harm. Parties bringing an appeal have a high evidentiary threshold to meet because they must prove the approved project will (as opposed to may) cause the harm prescribed [8].

\section{Wind Power Approvals and Appeals}

The first appeal of a wind power project under the regime created by the Green Energy Act (GEA) was filed in 2010, just months after the law was passed in the Ontario Legislature [9].

Prior to the new legislation, there had been appeals of wind power projects; these legal actions were presented to the Ontario Municipal Board, another quasi-judicial body [10].

A wind power project near Kincardine, Ontario was proposed and appealed in 2007 , on the basis of potential problems with health and safety. The appeal lasted seven weeks and heard from 22 witnesses and participants. The appellants alleged that care had not been taken to protect the public interest:

The appellants in their submissions to the Board alleged that the Municipality in approving the project in the form now before the Board, has abandoned its responsibility to protect the public interest and that the role of the appellants in this hearing is, among other things, to ensure that the public interest, as set out in the 2005 PPS and the [county name] Official Plan, is maintained, and that the community is protected from the negative impacts that they perceive will result from the approval of the [name] Wind Farm project. They contend that the standards being imposed by the Province and the Municipality are "simply not good enough to ensure the protection of health and safety to the residents of this community" and that some higher standards need to be considered $[10]^{1}$.

Data from the Incident Reports in government records provided in fulfillment of Freedom of Information requests, indicate that the number of Incident Report files for this power facility exceed 500, as of the end of 2017 [11].

Hundreds of complaints had already been filed about wind turbines erected in ${ }^{1}$ Ontario Municipal Board (2007), Ibid, 57. PDF available on request. 
power projects built before the new enabling legislation. A power project at Melancthon, Ontario garnered so many complaints that, according to a Canadian Broadcasting Corporation (CBC) news story and an interview with residents, environment ministry staff warned the ministry that there were problems. The family interviewed, who had filed many complaints, eventually had their home bought by the wind power developer in 2009, along with five other families [12].

Wind Concerns Ontario reviewed noise complaints collected by the government between 2006 to the end of 2014 and found more than 870 documents for both phases of the power facility at Melancthon [13].

Although documents show the Ontario government had received hundreds of complaints and warnings from staff about problems prior to enacting legislation supporting more wind power development [14], it proceeded with the Green Energy Act in 2009.

In the years that followed, more than 50 appeals were filed by individuals, community groups and municipalities across the province, as was allowed by provisions in the Environmental Protection Act (See Table 1 for an inventory of appeals). People in Ontario received no financial assistance in filing such appeals. The legal fees for the appeals ranged from several thousand to millions of dollars. In the case of the appeal of a project on the basis of risk to endangered wildlife and to human life due to proximity to two airstrips in Clearview, Ontario, which was supported by three municipalities and a citizen, the cost to taxpayers in those municipalities, was close to $\$ 800,000 \mathrm{CAD}[15]$.

While there were many appeals launched, several communities opted not to appeal, probably because of the "high evidentiary threshold", the limited time allowed to mount the appeal, and for financial considerations. While some parts of the hearings before the Tribunal were held in the rural communities, other hearings took place in the city of Toronto, requiring travel and expenses for lawyers and those attending these sessions.

The first appeal after the Green Energy Act was passed resulted in dismissal by the Tribunal, but the panel acknowledged the existence of problems, and appeared to encourage further exploration. In Erickson v. Director, MOE, the Tribunal concluded:

While the Appellants were not successful in their appeals, the Tribunal notes that their involvement and that of the Respondents, has served to advance the state of the debate about wind turbines and human health. This case has successfully shown that the debate should not be simplified to one about whether wind turbines can cause harm to humans. The evidence presented to the Tribunal demonstrates that they can, if facilities are placed too close to residents. The debate has now evolved to one of degree. [our emphasis] ... Just because the Appellants have not succeeded in their appeals, that is no excuse to close the book on further research. On the contrary, further research should help resolve some of the significant questions that the Appellants have raised [9] ${ }^{2}$.

${ }^{2}$ Erickson op cit., Conclusion, 207. 
Table 1. List of appeals of wind power approvals in Ontario, Canada by case number.

1) Tribunal \# 10-121 (WORD, PDF) Erickson v. MOE Related: 10-122 Chatham-Kent Wind Action Inc. v. MOE [Subject of Appeals: REA issued to Kent Breeze Wind Farms-20 MW Developers: Suncor, later sold to TransAlta]

2) 11-208 (WORD, PDF) Middlesex-Lambton Wind Action Group Inc. v. MOE [Subject of Appeal: REA issued to Zephyr Farms Ltd (other name: Brooke-Alvinston Wind Energy Project) - 10 MW Developers: Zephyr Farms Ltd/RES]

3) 11-228 (WORD, PDF) Preserve Mapleton Inc. v. MOE Related: 11-229 [Subject of Appeals: REA issued to Conestogo Wind Energy Centre-22.92 MW Developer: NextEra Energy]

4) 12-004 (WORD PDF) Chatham-Kent Wind Action Inc. v. MOE [Subject of Appeal: REA issued to Gesner Wind Farm LP-10 MW Developer: Saturn Power]

5) $\underline{12-018}$ (WORD, PDF) Haldimand Wind Concerns v. MOE Related: 12-015 12-016 [Subject of Appeals: REA issued to Summerhaven Wind Energy Centre-131.04 MW Developer: Next Era Energy]

6) 12-054 (WORD, PDF) Monture v. MOE Related: $\underline{12-072} \underline{12-073} \underline{12-077} \underline{12-078} \underline{12-079}-$

[Subject of Appeals: REA issued to Grand Renewable Wind Energy Park in Haldimand County 148.6 MW Developers: Pattern Energy Group and Samsung Renewable Energy]

7) 12-071 (WORD, PDF) Chatham Kent Wind Action Inc. v. MOE Related: $\underline{12-049} \underline{12-052} \underline{12-053} \underline{12-055} \underline{12-056} \underline{12-057} \underline{12-058} \underline{12-059} \underline{12-060}$ 12-061 12-062 12-063 12-064 12-065 12-066 12-067 12-068 12-069 12-070 12-076 12-099 [Subject of Appeals: REA issued to South Kent Wind Project-270 MW Developers: Pattern Energy Group, Samsung Renewable Energy]

8) 12-098 (WORD PDF) Haldimand Wind Concerns v. MOE Related: 12-100 [Subject of Appeals: REA issued to Port Dover and Nanticoke Wind Project in Norfolk/Haldimand Counties-104.4 MW Developer: Capital Power]

9) 12-144 (WORD PDF) Oppose Belwood Wind Farm Association v. MOE [Subject of Appeal: REA issued to Springwood Wind Project in Wellington County-8.2 MW Developer: wpd]

10) 12-148 (WORD, PDF) Manitoulin Coalition for Safe Energy Alternatives v. MOE [Subject of Appeal: REA issued to McLean's Mountain Wind Farm Project in the Town of Northeastern Manitoulin and The Islands, District of Manitoulin, Ontario-60 MW Developer: Northland Power]

11) 13-002 (WORD, PDF) Alliance to Protect Prince Edward County v. MOE Related: 13-003 Prince Edward County Field Naturalists v. MOE [Subject of Appeals: REA issued to Ostrander Point Wind Energy Park-22.5 MW Developer: Gilead Power]

12) 13-040 (WORD, PDF) Middlesex-Lambton Wind Action Group Inc. v. MOE [Subject of Appeal: REA issued to Bluewater Wind Energy Centre in Huron County-60 MW Developer: NextEra Energy]

13) 13-044 (WORD, PDF) Lewis v. MOE Related: 13-045 Municipality of North Middlesex v. MOE [Subject of Appeals: REA issued to Bornish Wind Energy Centre-72.9 MW Developer: NextEra Energy]

14) 14-052 (WORD, PDF) Municipality of Bluewater v. MOE Related: $14-051$ [Subject of Appeals: REA issued to Grand Bend Wind Farm-100 MW Developer: NextEra Energy]

15) 13-071 (WORD, PDF) CORE (Conserve our Rural Environment) v. MOE Related: 13-069 13-070 13-072 13-073 13-074 13-075 [Subject of Appeals: REA issued to Dufferin Wind Power Project in Melancthon Twp-99 MW Developer: Longyuan Canada Renewables/China Longyuan Power Group]

16) 13-079 (PDF) Engel v. MOE Related: $\underline{13-080}$ [Subject of Appeals: REA issued to HAF Wind Energy Project in West Lincoln Twp.-9 MW

Developers: Vineland Power (IPC). HAF Project and Vineland later sold to Loeffen Farms, Rankin Construction Inc. and IPC Energy]

17) 13-088 (WORD, PDF) Middlesex-Lambton Wind Action Group Inc. v. MOE Related: $\underline{13-084} \underline{13-085} \underline{13-086} \underline{13-087} \underline{13-089}$ [Subject of

Appeals: REA issued to St. Columban Wind Farm in Huron County-33 MW Developer: Veresen Inc.]

18) 13-096 (WORD, PDF) Second appeal of South Kent Wind Project with respect to an amendment issued by the Director, Ministry of the Environment to REA.

19) 13-097 (WORD, PDF) Drennan v. MOE Related: 13-098 [Subject of Appeals: REA issued to K2 Wind Power Project in Huron County-270 MW Developers: Capital Power, Samsung Renewable Energy, Pattern Energy Group]

20) 13-104 (WORD, PDF) MLWAG (Middlesex Lambton Wind Action Group) v. MOE Related: 13-102 13-103 Subject of Appeals: REA issued to Adelaide Wind Energy Centre in Township of Adelaide-Metcalfe-60 MW Developer: NextEra Energy]

21) 13-106 (WORD, PDF) Bain v. MOE Related: 13-107 13-108 [Subject of Appeals: REA issued to Ernestown Wind Park-10 MW Developer: Horizon Legacy/Horizon Wind Energy (Horizon Wind Energy acquired by Energias de Portugal in 2007 and became a part of EDP Renewables)] 22) 13-120 (WORD, PDF) Moseley v. MOE (with the assistance of Lake Superior Action Research Conservation (LSARC)) [Subject of Appeal: REA issued to Goulais Wind Project in District of Algoma-25 MW Developers: Sprott Power, later sold to Capstone Infrastructure] 23) 13-122 (WORD, PDF) Skydive Burnaby Ltd. V. MOE Related 13-121 [Subject of Appeals: REA issued to Wainfleet Wind Inc. (IPC) for the Wainfleet Wind Energy Project in Township of Wainfleet-9 MW Developer: IPC Energy]

24) 13-124 (WORD, PDF) Kroeplin v. MOE Related: 13-125 [Subject of Appeals: REA issued to Armow Wind Project in Municipality of Kincardine, Bruce County-180 MW Developer: Acciona, later sold to SP Armow Wind Ontario, a limited partnership between Samsung and Pattern]

25) 13-139 (WORD, PDF) MLWAG (Middlesex Wind Action) v. MOE Related: 13-138 [Subject of Appeals: REA issued to Adelaide Wind Power Project in Township of Adelaide-Metcalfe-40 MW Developer: Suncor]

26) 13-140 (WORD, PDF) Cham Shan Temple v. MOE Related: 13-141 13-142 Manvers Wind Concerns (MWC) v. MOE [Subject of Appeals: REA issued to Sumac Ridge Wind Project in City of Kawartha Lakes, Township of Manvers-10.25 MW Developer: wpd] 


\section{Continued}

27) 13-145 (WORD, PDF) Fata v. MOE Related: 13-146 [Subject of Appeals: REA issued to Bow Lake Wind Farm in District of Algoma-58.32

MW Developers: BluEarth Renewables Inc., Batchewana First Nation]

28) 14-007 (WORD, PDF) Van den Bosch v. MOE [Subject of Appeal: REA issued to East Durham Wind Energy Centre in Municipality of West Grey, Grey County-23 MW Developer: NextEra Energy]

29) 14-029 (WORD, PDF) Lewis v. MOE [Subject of Appeal: Renewable Energy Approval issued to Jericho Wind Energy Centre in Municipality of Lambton Shores, Township of Warwick, Lambton County, Municipality of North Middlesex-150 MW Developer: NextEra Energy]

30) 14-048 (WORD, PDF) Fairfield v. MOE Second appeal of the HAF Wind Energy Project with respect to amendments approved by Director, Ministry of the Environment pertaining to the setback distances from turbines to the property lines of non-participating property owners and to the removal of requirements to complete a post-construction monitoring report regarding raptor nesting habitat

31) 14-052 (WORD, PDF) The Municipality of Blue Water v. MOE Related: 14-051 [Subject of Appeals: REA issued to Grand Bend Wind Farm in Municipalities of Bluewater, South Huron, Huron East, West Perth; Huron County, Perth County-100 MW Developer: Northland Power] 32) 14-060 (WORD, PDF) The Municipality of Blue Water v. MOE Related: 14-059 [Subject of Appeals: REA issued to Goshen Wind Energy Centre in Municipalities of Bluewater and South Huron in Huron County-102 MW Developer: NextEra Energy]

33) 14-063 (WORD, PDF) Biddle v. MOE Related: 14-064 [Subject of Appeals: REA issued to Port Ryerse Wind Power Project in Norfolk County-10 MW Developers: UDI Renewables of Nanticoke, later sold to Boralex]

34) 14-065 (WORD, PDF) The Corporation of the County of Lambton v. MOE Related: 14-066 14-067 [Subject of Appeals: REA issued to Cedar Point Wind Power Project in Plympton-Wyoming, Lambton Shores and Warwick Township-100 MW Developers: Suncor, Next Era Energy] 35) 14-091 (WORD, PDF) Wallace v. MOE Second appeal of Dufferin Wind Power Project with respect to amendments issued by the Director involving several changes to the REA per EBR 012.2738.

36) 14-096 (WORD, PDF) MAWT (Mothers Against Wind Turbines Inc.) v. MOECC [Subject of Appeal: REA issued to Niagara Region Wind Farm in Townships of West Lincoln and Wainfleet, Town of Lincoln, Region of Niagara and Haldimand County-230 MW Developer: Enercon, later sold to Boralex]

37) 14-102 (WORD, PDF) Municipality of Clarington v. Ontario (MOECC)—Related: 14-103 Clarington Wind Farm [Subject of Appeals: REA issued to Clarington Wind Farm in Municipality of Clarington, Durham Region-8.1 MW Developer: Sierra Nevada Power (Ontario); Leader Resources Services contracted to develop, build and operate Project]

38) 15-009 (WORD, PDF) Corp of Municipality of Clarington v. Ontario (MOECC) - Related: 15-010 Clarington Wind Concerns v. Ontario (MOECC) [Subject of Appeals: REA issued to ZEP Wind Farm Ganaraska in Clarington, Durham Region-17.6 MW Developer: Capstone Power]

39) 15-011 (WORD, PDF) Dingeldein v. Ontario (MOECC) [Subject of Appeal: REA issued to ZEP Wind Facility in Municipality of Grey Highlands-10 MW Developer: Capstone Power]

40) 15-026 (WORD, PDF) Fohr v. Ontario (MOECC) [Subject of Appeal: REA issued to Grey Highlands Clean Energy Project-18.45 MW Developer: Capstone Power]

41) 15-028 (WORD, PDF) East Oxford Alliance Inc. v. Ontario (MOECC) [Subject of Appeal: REA issued to Gunn's Hill Wind Farm in Norwich Township, Oxford County-18 MW Developer: RES/Prowind Canada]

42) 15-037 (WORD, PDF) SLWP (Settlers Landing Wind Project) Opposition Corp v. Ontario (MOECC) [Subject of Appeal: REA issued to Settlers Landing Wind Park in Kawartha Lakes- 10 MW Developer: Capstone Infrastructure]

43) 15-041 (WORD, PDF) Hutton v. Ontario (MOECC) Related: 15-042 [Subject of Appeals: REA issued to Meyer Wind Farm in Municipality of Kincardine, Bruce County-4 MW Developer: Sierra Nevada Power (Ontario)]

44) 15-053 (WORD, PDF) SR (Snowy Ridge) Opposition Corp v. Ontario (MOECC) [Subject of Appeal: REA issued to Snowy Ridge Wind Park in City of Kawartha Lakes-10 MW Developer: Capstone Infrastructure]

45) 15-066 (WORD, PDF) Hutton v. Ontario (MOECC) Related: 15-067 [Subject of Appeals: REA issued to Majestic Wind Farm in Municipality of Kincardine, Bruce County-2 MW Developer: Sierra Nevada Power (Ontario)]

46) 15-068 (WORD, PDF) Hirsch v. Ontario (MOECC) Related: 15-069 15-070 [Subject of Appeals: REA issued to White Pines Wind Project in Prince Edward County-59.45 MW Developer: wpd]

47) 15-084 (WORD, PDF) APAI (Association to Protect Amherst Island) v. Ontario (MOECC) [Subject of Appeals: REA issued to Amherst Island Wind Project-74.3 MW Developer: Windlectric Inc., a subsidiary of Algonquin Power]

48) 16-036 (WORD, PDF) Wiggins v. Ontario (MOECC) Related: 16-037 16-038 16-039 16-040 16-041 16-042 [Subject of Appeals: REA issued to Fairview Wind Project in Township of Clearview, Simcoe County-18.4 MW Developer: wpd]

49) 16-076 (WORD, PDF) Jakubec v. Ontario (MOECC) [Subject of Appeal: REA issued to North Kent 1 Wind Project in Municipality of Chatham-Kent-100 MW Developer: Pattern Energy Group and Samsung Renewable Energy]

50) 17-074 (WORD, PDF) APPEC v. MOECC—Second appeal of White Pines Wind Project with respect to several amendments issued by the Director, Ministry of the Environment to REA.

51) 18-028 (WORD, PDF) Concerned Citizens of North Stormont v. Ontario (MOECC) [Subject of Appeal: REA issued to Nation Rise Wind Farm in Township of North Stormont, United Counties of Stormont, Dundas and Glengarry-100 MW Developer: EDP Renewables]

Sources: Environment and Land Tribunals https://elto.gov.on.ca/tribunals/ert/about-the-ert/. 
Other communities, however, were not encouraged by the legal test set for the Appellants. For example, on Manitoulin Island, citizens-both First Nations and non-First Nations-filed an appeal based on the risk to both health and the environment but withdrew after receiving information through a Freedom of Information (FOI) request. Their representative told the media:

The FOI shows that back in 2009, before the Green Energy Act, several civil servants in the ministry right up to the Assistant Deputy Minister knew all about the health problems from wind turbine noise. Some admitted to experiencing the effects. Others stated it contravened the [noise regulation limits]. But today, those turbines are still turning, continuing to victimize the people of this province. ... The deck is stacked against all of us in rural Ontario [16].

Moreover, the Appellant in that case sought clarification on the precise definition of "serious harm" from legal counsel for the environment ministry, but received the response that the ministry "has no general statement which sets out a position on the definitions of the terms used in the legislation." [17].

\section{Wind Turbine Noise: A Unique Source}

Knowledge of the noise emissions produced by industrial-scale or grid-scale wind turbines has evolved, and it is acknowledged that there is a range of noise emissions unique to wind power generators.

Acoustics specialists and educators Jerry Punch and Richard James conclude in their 2016 literature review:

The preponderance of evidence on this point leads to the conclusion that WTN [wind turbine noise] has special acoustic characteristics that distinguish it from other industrial sounds. A primary feature is that it consists of measurable energy down to below $1 \mathrm{~Hz}$ [18].

The Council of Canadian Academies, commissioned by Health Canada [19] to conduct a review acknowledged in its 2015 report a connection between the noise emissions and "annoyance" (a medical term denoting stress or distress):

The evidence consistently shows a positive relationship between outdoor wind turbine noise levels and the proportion of people who report high levels of annoyance $[19]^{3}$.

The Council also stated that current methods of noise measurement may not capture the full range of noise emissions:

Measurement of sound for health surveillance and research uses standard methods. The most commonly used methods include A-weighting, which emphasizes the frequencies according to human hearing sensitivity, and deemphasizes low and very high frequencies. Although A-weighted measurement is an essential method, it may fail to capture the low-frequency

${ }^{3}$ Council of Canadian Academies (2015), Ibid., xv. 
components of wind turbine sound. In addition, measurement is often averaged over time (Leq), which does not convey changes in sound pressure levels occurring in short periods (for example, within a second). Time-averaged measurement may thus fail to capture amplitude modulation.

A-weighted measurements are an important first step in determining people's exposure to audible sound in most cases, but more detailed measurements may be necessary in order for researchers to fully investigate the potential health impact of specific sources of wind turbine noise. The metrics of sound exposure most relevant to potential health outcomes are not completely understood, however, and remain an important area for further research $[19]^{4}$.

The methods described by the Council are those used by many jurisdictions to assess regulatory compliance, including the Province of Ontario; the Council recommended change: "The Panel recognizes the usefulness of measuring night-time exposure to sound from wind turbines, which is currently not widely undertaken in Canada." [19] ${ }^{5}$.

\section{The Appeals: A Matter of Degree}

Several examples of appeals launched since 2009 were selected for our review of the grounds for appeal, followed by a review of government records of complaints associated with those projects post-commencement of operations. Most of the appeals were based on concerns about human health, but many also included concerns about the risk of "serious and irreversible harm" to wildlife and the environment.

\subsection{Environmental Noise}

Approval for 140, 2.3-megawatt turbines in Ashfield-Colborne-Wawanosh, near Goderich, Ontario was granted on July 23, 2013. An appeal was subsequently filed on August 6, based on the grounds of serious harm to human health.

As part of the evidence presented, several "post-turbine witnesses," people who had lived or were living in proximity to industrial-scale wind turbines, testified under oath or affirmation before the Tribunal. One witness, who lived within 800 metres of a turbine, reported several health effects that the witness connected to operation of the wind turbine, specifically "sleep deprivation, ringing in the ears, increased blood pressure and heart rate". [20].

A second witness, who lived inside another large wind power project, described impacts from the wind power infrastructure, specifically the transformer station: "poor sleep, shakiness, headaches, pressure in the chest and ringing in the ears. ... the witness states it was the vibration and humming inside the home that was the cause of concern" $[20]^{6}$. 
The appeal was dismissed. However, in the Tribunal's Decision, it was noted that the Director for the Ministry of the Environment stated that the Tribunal "should not rely on the evidence of the post-turbine witnesses" $[20]^{7}$ and further, that no medical professional had testified as to their symptoms and as such, "the witnesses admitted that they were self-diagnosed." $[20]^{8}$.

The power facility began commercial operation in June, 2015 [21]. Following a review of documents supplied after a Freedom of Information (FOI) request by Wind Concerns Ontario, it was determined that the Ontario environment ministry received 413 complaints about this particular facility in 2015-and another 178 in 2017, for a total of 592 (supplied) complaint records [22]'.

Excerpts from formal government pollution Incident Reports contain descriptions of the problems experienced, as recorded by government staff, including notations of adverse health effects. For example:

... unbearable ... torture ... It gave me a splitting headache like I do not think I have ever had before. I was nauseous. I was shaky. My ear was popping. It puts the fear into me as to what this is doing to us ... [23].

$\ldots$ drives a person insane when it goes on for hours ... we are being impacted health-wise and are extremely agitated with the noise ... says ears popping and feeling dizzy [24].

The turbines have been producing very loud whomping, swooshing, thumping, pounding and churning noise ... We were awakened throughout the night ... This morning I feel terrible. I have tension in my face and neck, my heart is racing. I feel extreme agitation and stress [25].

This complaint is about what happened around 0200 hours and later this morning as I was trying to sleep. This noise causes sleep deprivation, ringing in my ear and ear pain. I was disturbed by the roaring that sounded like a jet engine trying to take off-starting and stalling ... This led to ringing in my ear and then pain in my ear. The after effect is a headache. I would say there are also vibrations ... [26].

According to government records of Incident Reports, government staff communicated with the power operator about the conditions of the Renewable Energy Approval, one of which is to provide post-operational acoustic audits, and another to investigate and resolve complaints. The government documents show that the local District Office staff, noting the number of complaints about the project, requested in 2017 that the operator implement a noise mitigation plan and file the mandated audit. The company responded that in its view, "the current circumstances do not objectively establish reasonable and probable grounds to require interim mitigation measures" $[26]^{10}$.

${ }^{7}$ Drennan v. Director, Ibid., Case Nos 13-097, 13-098 at para. 97.

${ }^{8}$ Drennan v. Director, Ibid., Case Nos 13-097, 13-098 at para. 98.

${ }^{9}$ There is some question as to the number of documents provided, according to Wind Concerns Ontario. Citizens kept records of many more complaints than were surrendered in the request, and there were no records at all from at least one District Office.

${ }^{10}$ FOI request A-2018-05726, Ontario reference 8166-ARELWN, Ibid., 12. 
Eventually, almost four years after the power facility began operation, the ministry did issue a Provincial Officer's Order in May, 2019, according to its powers under the EPA. The Order required the operator to have an acoustical consultant "develop interim abatement measures to be immediately implemented to ensure that the Sound Levels from the Equipment comply with the Noise Performance Limits" which was to include "limiting the number of hours during a twenty-four (24) period [sic] during which the Equipment operates" and/or "curtailing the operation of the Equipment under specific operating conditions" [27].

In other words, the government was responding to the citizen complaints out of concern that the project may not have been operating in compliance with noise regulations, and had not met the protective conditions of its Renewable Energy Approval.

This situation was the focus of media attention; according to media reports, more than half of the turbines in the large power project were thought to be out of compliance [28]. (The power operator applied for and achieved a Stay from the government; new noise measurement information is under review.)

\subsection{Adverse Health Effects}

As illustrated in Table 1, many other appeals of renewable energy approvals took place in Ontario. Almost all were based on concerns about human health, usually related to noise emissions.

What follows is a selection of excerpts from government records of noise complaints filed formally with either the District Offices of the environment ministry, or via the special "Spills Action" telephone number set up by the government to receive such calls. Again, the ministry staff making the notes included references to the reports of adverse health effects.

[Caller] reports that the wind turbines are affecting [redacted] sleep. Caller states that in the past 14 days, he wakes up after a couple of hours of sleep with a headache and teeth hurting [29].

... phone conversation with complainant. While wind turbines sound like a plane at height constantly flying over her house, noise is not a concern [redacted] experiencing more ... I encouraged complainant to seek medical advice and if she got something in writing it would be passed onto the Niagara Region Health Unit. ... I also encouraged her to contact the Wind Farm operators directly ... [30].

... noise from the turbine constant since Monday, like a jet and tonal hum. Caller reports [redacted] is experiencing headaches and a lack of sleep due to the noise [31].

I have an ongoing complaint regarding the wind turbines of the [project name]. The noise that is being generated from these turbines is becoming unbearable. I have tried to suck it up because they are here and I am sure they are not going to be taken down. I can constantly hear the swoosh of 
the blades when I am in my backyard. But the factor that is becoming unbearable is that it wakes me in the night with the constant swooshing sound, it gets to the point that is I am not able to sleep. Father's Day was unbearable ... something needs to be done as I am unable to function on 3 hours of sleep per night for the past week [32].

Caller reported a wind turbine noise complaint described as a faint washing machine with noticeable pressure and pulsating sensations from their private residence. They rated it $10 / 10$ as it woke them up from sleeping. Caller $\mathrm{i}[\mathrm{s}]$ unsure which project is causing the noise as they are surrounded by the [names] projects [33].

When the initial project, [project name] came online to the north of our property, I began experiencing severe health impacts almost immediately: tinnitus, ear pressure, head pressure, nausea, abdomen churning [etc.]. These symptoms were intermittent and increased in frequency and severity, eventually included decreased cognition and ongoing memory issues as exposure continued ... our suffering continued increasing to the point where we seriously considered leaving our home ... By November 2015, I was no longer able to work [34].

\subsection{Well Water Issues}

The issue of well water quality has arisen in a number of areas in Ontario and appears in government records of citizen complaints. One appeal was filed on the basis of the risks of serious harm to human health and serious and irreversible harm to the environment from a proposed wind power facility. As the Appellant withdrew the appeal there is no Decision and thus no details are available on the evidence related to the specific risk presented to the Environmental Review Tribunal [35]. However, it is possible to determine from documents associated with the appeal, that the Appellant was concerned about the effect of the proposed wind turbines on groundwater:

The proposed additional testing and analysis work described in Exhibits $\mathrm{H}, \mathrm{J}$ and $\mathrm{L}$ to the [Appellant] Affidavit will not assist the Tribunal in answering the question of whether or not construction and operation of the [project name] turbines and their foundations will cause adverse effects on groundwater $[35]^{11}$.

The possibility that groundwater could be affected by the vibration from the construction and operation of the wind turbines was covered in the local media, and included dramatic photographs provided by the Appellant and a local activist group depicting drinking water with black or brown particles suspended in the water from wells owned by residents living nearby other, operating wind power projects, as well as interviews with property owners whose water well function had been adversely affected [36].

\footnotetext{
${ }^{11}$ Jakubec v. Director, Ibid., para. 21.
} 
Documents provided to Wind Concerns Ontario as part of a request for records of complaints about wind turbine noise included staff-prepared Incident Reports of complaints about well water. Several excerpts follow:

... the Ministry received a complaint from [redacted] have advised us that they believe the operation of three wind turbines within the [project name] windfarm caused black sedimentation in his well water. Specifically, the fall of 2016 they experienced increased sedimentation in their well water which required the installation of a number of filters on their water system. They indicated that after 6 or 7 months, they decided to move away from the filters, and instead installed a stand-alone bulk water tank and a new water pump.... the water well has been completely disconnected from their house [37].

... called to say his well went dry during the weekend. He got it going Tuesday, but the water is quite turbid." [According to the environment ministry notes, water sampling was scheduled through the wind power operator contractor.] [38].

Caller is complaining of visual differences (cloudy, coloured, grit) and unusual odor from her well water ... water filters looked different than they have in the past. They indicate that construct activity has been going on in the vicinity of their home lately and believe the two are connected [38 $]^{12}$.

An email provided in the records via the Freedom of Information request contained a comment from a ministry engineer about a "vibration assessment" prepared by a consultant for a wind power operator:

Based on [redacted] vibration assessment and information presented to the ministry $\underline{I}$ am not satisfied with the level of details and content of their report/assessment. The report misrepresented separation distances between monitored water well and complainant water well. [emphasis by the staff engineer] [38 $]^{13}$.

The environment ministry and the local Medical Officer of Health maintained that there was no danger to the public [39]. Complaints and media coverage continued, however, and in July, 2019, the government announced it was launching a public health investigation of the water situation. In an announcement the local Member of Provincial Parliament stated:

The five-member independent panel will consist of four experienced toxicologists and one local geologist. All members are independent from government and are experienced toxicology professionals that have served on advisory committees.

The panel is empowered to take a fresh look at new samples collected from certain water wells in Chatham-Kent where residents have raised questions about water quality. Samples from up to 189 private wells will be taken by a third-party business and tested by a commercial laboratory [40].

${ }^{12}$ FOI request A-2018-05726, Ibid., p. 005901. No IR number. PIN 007420039.

${ }^{13}$ FOI request A-2018-05726, Ibid., p.005940. Email dated November 24, 2017. 


\section{Discussion}

The goal of this review was to determine whether the citizen concerns about industrial-scale wind turbine development raised at appeals of the project approvals were borne out in any way by lived experiences after the power generation facilities began operation.

As noted, the grounds for appeals were limited and the evidentiary burden for Appellants in the appeals was substantial. Few appeals in Ontario were successful.

Although witnesses currently living within wind power facilities presented evidence under oath in the appeals as to their real-life experiences, and the Tribunal accepted their testimony as "sincere," their testimony nevertheless did not carry much weight. As explained by lawyer Albert Engel:

In Bovaird, and several subsequent decisions, the Tribunal commented as follows on why the evidence of post-turbine witnesses was unreliable:

The Tribunal does not question the sincerity of the post-turbine witnesses in giving their evidence. They acknowledge that the identification of their adverse health effects is through their own self-diagnosis. They also acknowledge that they have reached personal conclusions regarding the issue of causation. Several of them assert that they have had to do so, because they maintain that medical professionals either have no knowledge regarding the effects of wind turbines, or are skeptical or dismissive of the possibility that wind turbines can negatively affect human health. Nevertheless, none of the post-turbine witnesses adduced any medical opinion from their health practitioners which confirms that they have experienced symptoms caused by wind turbines. The Tribunal does not question that the post-turbine witnesses have experienced the symptoms they have described [41].

However, our review of government documents post-appeal and after commencement of facility operations indicates that there are significant complaints related to the operation of wind turbines, specifically about environmental impact in the form of noise pollution and possible disturbance of groundwater and water wells.

There is also new evidence that some Ontario property owners have been so disturbed by living within the power facilities that they contemplated leaving or did leave their homes permanently [42].

There were enough complaints that one Ontario jurisdiction launched a public health investigation under the authority of the Health Promotion and Protection Act (HPPA, 1990). In its final report published in 2019, the Huron County Health Unit said that "analysis of study participants confirmed an association between wind turbine noise exposure and annoyance. Of participating households within one kilometre of at least one wind turbine, $58 \%$ had at least one person reporting they were bothered, disturbed or annoyed by noise or light" [43].

In a review of the 2017 records provided by government following a Freedom of Information request, 42 percent of the 674 Incident Reports were found to have 
some mention of the occurrence of adverse health effects. Again, that concern was the basis of most of the appeals of wind power facility approvals [44].

Several academic articles have been published on how Ontario's wind power program has been implemented during the past decade. Baxter et al., 2015 commented that the removal of local land-use planning was problematic and that the government treatment of citizens complaining about adverse effects from living with the wind power generators was flawed.

... [R]ather than dismissing health claims as groundless or inconsequential, policy-makers should take a precautionary approach so as to more thoroughly address the factors that contribute to frustration on the part of the host communities. ... This must be coupled with diligent enforcement of the responsibility of wind companies to respond to noise complaints throughout the life of the project [45].

Another academic review by McRobert et al. looked at the appeal process, and the basis for citizen appeals. It concluded that it was an unsatisfactory method for dealing with concerns, which the authors termed "genuine":

To urban-based environmentalists, resistance to wind and solar farms is often seen as nothing more than Not in My Backyard attitudes (NIMBYism), and turbine opponent concerns are trivialised. ... [M]any communities opposed to these projects have genuine concerns about impacts on environmental integrity, viewscapes, food production, and social fabric. ... Moreover, the supposed "NIMBY syndrome" has been criticised by environmental justice scholars and others as an oversimplification of opposition that more accurately is based on a complex mix of factors including perceptions about a lack of procedural and distributive justice in approval processes [46].

\section{Conclusions}

The Government of Ontario holds thousands of records of citizen complaints in the form of Incident Reports, many of which are reports of excessive noise and vibration; a significant number includes accounts of the occurrence of adverse health effects. The basis for most of the appeals of the approvals for the power generation projects was citizens' concern about effects on health from wind turbine noise emissions.

Moreover, complaints continue to be filed despite regulations and approval conditions that specify clearly that the reasons for these complaints must be addressed and measures are taken to prevent recurrence [47]. There is evidence to suggest that current regulations are not adequate to protect health.

Further work could focus on the apparent disconnect between government policy and action taken by government employees, as shown in the complaint records. 
While the provincial government in Ontario has since returned local land-use planning for power projects to municipalities, the process for recognition of concerns, acknowledgement of past problems, and appeals of industrial-scale power projects could benefit from a robust independent review so as to ensure social and procedural justice.

Based on this review of government reports of environmental pollution including the formal Incident Reports, it appears that the people who were concerned about the risks to the environment and human health were not wrong. Those concerns-which led them to spend substantial amounts of money while participating in an unfamiliar, stressful quasi-judicial process-are now the reason for a significant number of complaints to government.

The people await the help and protection that was promised to them.

\section{Acknowledgements}

The authors wish to thank Grace Howell Ed.D. of Western University, Deb Hughes $\mathrm{MScN}$ of McMaster University, and Kathleen Coulter J.D. of Eric K. Gillespie Law for their reviews of this paper. The authors acknowledge the contribution of the people of rural Ontario who continued to file reports of environmental and adverse health effects with their government in hope that someday, something would be done to help them.

\section{Conflicts of Interest}

The authors declare no conflicts of interest regarding the publication of this paper.

\section{References}

[1] Orangeville.com (2009) Municipalities Want Changes to Green Energy Act. https://www.orangeville.com/news-story/1482705-municipalities-want-changes-togreen-energy-act

[2] Canadian Press (2009) Ontario Passes Bill to Boost Green Projects, Create Jobs. https://www.cbc.ca/news/canada/toronto/ontario-passes-bill-promising-to-boost-gr een-projects-create-jobs- 1.860584

[3] Trebilcock, M. (2011) Speaking Truth to Wind Power. In: Wilson, J., Ed., Dirty Business: The Reality of Ontario's Rush to Wind Power, Wind Concerns Ontario, Ottawa, 8.

[4] Ferguson, R. (2009) McGuinty Vows to Stop Wind Farm NIMBYs. Toronto Star. https://www.thestar.com/news/ontario/2009/02/11/mcguinty_vows_to_stop_windfa rm_nimbys.html

[5] Environment and Land Tribunals (2010) A Guide to Appeals by Members of the Public Regarding Renewable Energy Approvals under Section 142.1 of the Environmental Protection Act.

https://elto.gov.on.ca/tribunals/ert/about-the-ert/renewable-energy-appeals

[6] Environmental Protection Act RSO 1990, Part 1, Section 5. https://www.canlii.org/en/on/laws/stat/rso-1990-c-e19/latest/rso-1990-c-e19.html

[7] Environmental Protection Act RSO 1990, 47.5, Paragraph (3). https://www.canlii.org/en/on/laws/stat/rso-1990-c-e19/latest/rso-1990-c-e19.html?s earchUrlHash=AAAAAQAGYXBwZWFsAAAAAAE\&offset $=0$ 
[8] Willms \& Shier (2012) Turbine Opponents Whistling in the Wind? https://www.willmsshier.com/resources/details/turbine-opponents-whistling-in-the -wind-

[9] Erickson v. Director, MOE. Case Nos 10-121/10-122.

[10] Ontario Municipal Board (2007) Decision/Order No: 1989. PL060986. J. P. Atcheson, Member. Issue Date: Jul. 16, 2007. PDF Copy Available on Request.

[11] Wind Concerns Ontario (2020) Response to Wind Turbine Noise Complaints by Ontario's Environment Ministry, 25.

http://www.windconcernsontario.ca/wind-turbine-noise-complaints-mount-docum ents-show

[12] CBC News (2011) Ontario Wind Farm Risks Downplayed.

https://www.cbc.ca/news/canada/ont-wind-farm-health-risks-downplayed-docume nts-1.1122648

[13] Wind Concerns Ontario, op cit, 25.

[14] Hall, C. (2010) Memorandum, Senior Environmental Officer, Guelph District Office. PDF Copy Available on Request.

[15] Simcoe.com (2017) Here's How Much the Clearview Wind Turbine Fight Cost Local Municipalities.

https://www.simcoe.com/news-story/7574793-here-s-how-much-clearview-wind-tu rbine-fight-cost-local-municipalities

[16] CBC News (2012) Wind Farm Opponents Abandon Appeal. https://www.cbc.ca/news/canada/ont-wind-farm-health-risks-downplayed-docume nts-1.1122648

[17] Email from Danielle Meuleman, Crown Counsel, Ministry of the Attorney General Ontario to Raymond Beaudry of the Manitoulin Coalition for Safe Energy Alternatives, November 29, 2012. PDF Available on Request.

[18] Punch, J. and James, R. (2016) Wind Turbine Noise and Human Health: A Four-Decade History of Evidence that Wind Turbines Pose Risks.

https://docs.wind-watch.org/Punch-James-Wind-Turbine-Noise-16-09-30.pdf

[19] Council of Canadian Academies (2015) Understanding the Evidence, II. https://cca-reports.ca/wp-content/uploads/2018/10/windturbinenoisefullreporten.pdf

[20] Drennan v. Director, Ministry of the Environment, Case Nos 13-097, 13-098 at Para. 93.

[21] K2 Wind. https://k2wind.ca

[22] Wind Concerns Ontario (2020) op cit. 4-5.

[23] Wind Concerns Ontario (2020) Response to Wind Turbine Noise Complaints by Ontario's Environment Ministry, Third Report 2017. Ontario Reference IR 0278-ATBLVV.

[24] Wind Concerns Ontario (2020) Response to Wind Turbine Noise Complaints by Ontario's Environment Ministry, Third Report 2017. Ontario Reference IR 7583-AU\&NRB.

[25] FOI Request A-2018-05726, Ontario Reference 1431-AQ8QJD, Dated August 11, 2017, 003696-003698.

[26] FOI Request A-2018-05726, Ontario Reference 8166-ARELWN, Dated September 21, 2017, 003466-003468.

[27] Ontario Ministry of Environment, Conservation and Parks. Provincial Officer's Order No. 8710-BBPLMC. 2019. 1-2.

[28] Miller, S. and CTV News (2019) Wind Farm Ordered to Reduce Noise. May 27, 2019. https://london.ctvnews.ca/wind-farm-ordered-to-reduce-noise-1.4438989 
[29] FOI Request op cit, IR 1084-AHWNM6 St. Columban Wind Project. Appealed Dixon v. Director, MOE. Case Nos. 13-084-13-089.

[30] FOI Request op cit, IR 3438-AJCRS2. Vineland Project. Fairfield v. Director, MOE 14-048.

[31] FOI Request op cit, IR 0035-AJ2SYT. Niagara Region Wind Farm. Mothers against Wind Turbines v. Director, MOE. Case No. 14-096.

[32] FOI Request op cit. IR 7814-ANSPM3. Settlers Landing Wind Park. Settlers Landing Wind Park Opposition v. Director, MOE, Case No. 15-037.

[33] FOI Request op cit., IR8700-ANE8PY. Summerhaven Wind Energy Centre. Monture v. Director, MOE. Case Nos. 12-015-12-018.

[34] FOI Request op cit., Letter Dated March 27, 2017, Received in Owen Sound District Office March 29, 2017, 002638-002639. Grand Bend. Gillespie v. Director, MOE Case Nos. 14-051-14-052.

[35] Jakubec v. Director, Ministry of Environment and Climate Change. Case No. 16-076. http://www.ert.gov.on.ca/CaseDetail.aspx? $\mathrm{n}=16-076$

[36] CBC News (2018) Well Water Drinkers in Chatham-Kent Asking PCs to Investigate Sediment Findings.

https://www.cbc.ca/news/canada/windsor/well-water-chatham-kent-investigation-s ediment-1.4836497

[37] FOI Request A-2018-05726, pp. 005897-005898. Ontario Reference IR 6117-ARVPQ2.

[38] FOI Request A-2018-05726, Ontario Reference 0403-B4GKRX, p. 005873.

[39] Ensing, C. and CBC News Windsor (2018) Chatham-Kent Families Fear They Won't Have Clean Drinking Water. Feb. 5, 2018.

https://www.cbc.ca/news/canada/windsor/water-wells-contaminated-ministry-envir onment-chatham-kent-turbines- 1.4521473

[40] McNaughton, M. (2019) Ontario Conducting Health Hazard Investigation. http://montemcnaughtonmpp.ca/2019/07/19/ontario-conducting-health-hazard-inv estigation

[41] Engel, A. (2014) Legal Requirements for Human-Health Based Appeals of Wind Energy Projects in Ontario. Front Public Health, 2, 248.

https://www.ncbi.nlm.nih.gov/pmc/articles/PMC4248670/\#fn8 https://doi.org/10.3389/fpubh.2014.00248

[42] Krogh, C.M., McMurtry, R.Y., Dumbrille, A., Hughes, D. and Gillis, L. (2020) Preliminary Results: Exploring Why Some Families Living in Proximity to Wind Turbine Facilities Contemplate Vacating Their Homes-A Community-Based Study. Open Access Library Journal, 7, e6118. https://doi.org/10.4236/oalib.1106118

[43] Huron County Health Unit (2019) Final Report Huron County Wind Turbine Study about Noise, Vibration and Light 2019, 4.

[44] Wind Concerns Ontario (2020) op cit, 16.

[45] Fast, S., Mabee, W., Baxter, J., Christidis, T., Driver, L. and Hill, S. (2016) Lessons Learned from Ontario Wind Energy Disputes. Nature Energy, 1, Article No. 15028. https://doi.org/10.1038/nenergy.2015.28

[46] McRobert, D., Tennent-Riddell, J. and Walker, C. (2016) Ontario's Green Economy and Green Energy Act [sic]: Why a Well-Intentioned Law Is Mired in Controversy and Opposed by Rural Communities. Renewable Energy Law and Policy, 7, 99.

[47] Ontario Ministry of Environment and Climate Change (2018) Renewable Energy Approval Nation Rise Wind Farm, Operations and Maintenance, W2 (3), 36. https://s3.amazonaws.com/Citations/nationrise/REA+No.+0871-AV3TFM.pdf 